\title{
Knowledge of Brucellosis, Health-Seeking Behaviour, and Risk Factors for Brucella Infection amongst Workers on Cattle Farms in Gauteng, South Africa
}

\author{
Krpasha Govindasamy ${ }^{1, * \mathbb{D}}$, Eric M. C. Etter ${ }^{1,2,3} \mathbb{D}^{\mathbb{D}}$, Bernice N. Harris ${ }^{4} \mathbb{D}$, Jennifer Rossouw ${ }^{5} \mathbb{D}_{\text {, }}$ \\ Darrell A. Abernethy $6,7,+(\mathbb{D}$ and Peter N. Thompson $1,+\mathbb{D}$
}

1 Department of Production Animal Science, Faculty of Veterinary Science, University of Pretoria, Pretoria 0110, South Africa; eric.etter@cirad.fr (E.M.C.E.); peter.thompson@up.ac.za (P.N.T.)

2 Centre de Cooperation Internationale en Recherche (CIRAD), UMR Joint Research Unit, Animals Health Territories Risks Ecosystems (ASTRE), 34070 Montpellier, France

3 CIRAD, Institut national de la recherche agronomique (INRA), University Montpellier, 34070 Montpellier, France

4 School of Health Systems and Public Health, University of Pretoria, Pretoria 0031, South Africa; bernice.harris@up.ac.za

5 Centre for Emerging Zoonotic and Parasitic Diseases, National Institute for Communicable Diseases, Sandringham, Johannesburg 2192, South Africa; jennyr@nicd.ac.za

6 Centre for Veterinary Wildlife Studies, Faculty of Veterinary Science, University of Pretoria, Pretoria 0110, South Africa; daa47@aber.ac.uk

Citation: Govindasamy, K.; Etter E.M.C.; Harris, B.N.; Rossouw, J.; Abernethy, D.A.; Thompson, P.N. Knowledge of Brucellosis,

Health-Seeking Behaviour, and Risk Factors for Brucella Infection amongst Workers on Cattle Farms in Gauteng, South Africa. Pathogens 2021, 10, 1484. https://doi.org/10.3390/

pathogens10111484

Academic Editors: Andrea Ianni and Tommasangelo Petitti

Received: 25 October 2021

Accepted: 11 November 2021

Published: 14 November 2021

Publisher's Note: MDPI stays neutral with regard to jurisdictional claims in published maps and institutional affiliations.

Copyright: (c) 2021 by the authors. Licensee MDPI, Basel, Switzerland. This article is an open access article distributed under the terms and conditions of the Creative Commons Attribution (CC BY) license (https:/ / creativecommons.org/licenses/by/ $4.0 /)$
7 Aberystwyth School of Veterinary Science, Institute of Biological, Environmental and Rural Sciences, Aberystwyth University, Penglais, Aberystwyth SY23 3FL, UK

* Correspondence: krpasha@gmail.com; Tel.: +27-73147-8025

+ These authors were jointly responsible for supervision.

Abstract: Brucellosis in humans is under-detected and underreported in sub-Saharan Africa. Risk factors associated with Brucella infection and health seeking behaviour in response to brucellosis-like symptoms, amongst cattle farm workers and veterinary officials in South Africa, are unknown. Farm workers and veterinary officials $(N=230)$ were screened for brucellosis using commercial Rose Bengal Test $\left(\right.$ RBT $\left.^{\circledR}\right)$, IgM Enzyme-linked Immunoassay (ELISA) ${ }^{\circledR}$, IgG ELISA $^{\circledR}$ and the BrucellaCapt ${ }^{\circledR}$ test. Knowledge of brucellosis and risk factors for exposure to Brucella were also investigated. Seroprevalence varied according to test used: $10.1 \%\left(\mathrm{RBT}^{\circledR}\right), 20.9 \%\left(\operatorname{IgG}\right.$ ELISA $\left.^{\circledR}\right)$ and $6.5 \%\left(\right.$ BrucellaCapt $\left.^{\circledR}\right)$. Only $22.2 \%(6 / 27)$ of veterinary officials opt to visit a clinic, doctor, or hospital in response to selfexperienced brucellosis-like symptoms, compared to $74.9 \%(152 / 203)$ of farm workers $(p<0.001)$. Of the BrucellaCapt ${ }^{\circledR}$ seropositive participants, 53\% (7/15) did not visit a clinic in response to brucellosislike symptoms. Weak evidence of an association between the handling of afterbirth or placenta and infection of a short evolution (RBT ${ }^{\circledR}, \operatorname{IgM}_{\text {ELISA }}{ }^{\circledR}$ and IgG ELISA ${ }^{\circledR}$ seropositive) was found (OR $=8.9,95 \% \mathrm{CI}: 1.0-81.1, p=0.052)$, and strong evidence of an association between this outcome and the slaughter of cattle (OR $=5.3,95 \%$ CI: $1.4-19.6, p=0.013)$. There was strong evidence of a positive association between inactive/resolved infection and veterinary officials vs. farm workers exposed to seropositive herds (OR $=7.0,95 \%$ CI: 2.4-20.2, $p<0.001$ ), with a simultaneous negative association with the handling of afterbirth or placenta (OR $=3.9,95 \% \mathrm{CI}: 1.3-11.3, p=0.012)$. Findings suggest a proportion of undetected clinical cases of brucellosis amongst workers on cattle farms in Gauteng.

Keywords: bovine; brucellosis; human; Brucella; B. abortus; South Africa; RBT ${ }^{\circledR} ;$ IgG ELISA ${ }^{\circledR} ; \operatorname{IgM}$ ELISA ${ }^{\circledR}$; BrucellaCapt ${ }^{\circledR}$

\section{Introduction}

Brucellosis is a neglected zoonotic disease of global health and economic importance [1-3]. Symptoms of brucellosis in humans are non-specific and are difficult to 
distinguish from those of other febrile illnesses [4]. They include malaise, anorexia, recurrent fever, muscular weakness, joint pain, back pain, and depression. The disease can also result in bone and testicular abscesses, endocarditis, and neurological complications and persons suffering from chronic brucellosis experience a loss of life years from persistent disability and time lost from daily activities [5].

Early detection of human brucellosis and initiation of the correct combination of antibiotics are critical for successful treatment and management of brucellosis [6] since there is no vaccine against the disease in humans [5,7]. Prevention of brucellosis in humans through public health intervention has been aimed at reducing the indirect transmission of Brucella bacteria through contaminated milk [8]. Reduction of infection in the animal host is usually by vaccination and test and slaughter activities conducted by governmental veterinary officials [9]. However, a lack of resource allocation to animal disease control programmes challenges the effectiveness of such programmes in low- and middle-income countries [10,11].

Poor knowledge of the zoonotic risk of brucellosis amongst people occupationally exposed to brucellosis has been identified as a further barrier to the control of livestock brucellosis and the continued spread of the disease amongst livestock [12,13]. Furthermore, such lack of knowledge is associated with ineffective precautionary behaviour needed to reduce self-exposure to contact with infected aborted material or infected cows at calving [14]. In addition, such lack of knowledge has been reported to result in inappropriate health behaviour in response to brucellosis-like symptoms which ultimately contributes to under detection and under diagnosis of brucellosis, or difficulties in medically treating clinical cases [15]. For example, self-medication for flu-like symptoms, or with an antibiotic at the suggestion of a pharmacist [6]. Other risk factors for human brucellosis have been reported to be related to the occupational status of the person $[16,17]$, type of animal handled and the duration of contact with animals [16,17] and consumption of raw milk [18].

Culture and molecular diagnosis of brucellosis are difficult [19], therefore, use is made of serological tests to detect exposure to Brucella $[7,20,21]$. Literature supports the use of the Rose Bengal test $\left(\mathrm{RBT}^{\circledR}\right)$ in developing countries [22] due to the affordability, ease of conducting the test and adaptability to test serum dilutions. It can detect $\operatorname{IgM}, \operatorname{IgG}$ and IgA and was found to be highly sensitive in short ("acute") and long ("chronic") evolution brucellosis cases when the test is optimised to have a $\mathrm{pH}$ capable of agglutinating blocking IgA antibodies and removing prozones. $\mathrm{RBT}^{\circledR}$ was found to also be highly specific in the sera of persons with no contact with Brucella and its ability to detect immunoglobulin $\mathrm{M}$ (IgM), immunoglobulin G (IgG) and immunoglobulin A (IgA) was comparable to that of the BrucellaCapt ${ }^{\circledR}$ test [22]. However, it is recommended that a complementary test be used with commercially available $\mathrm{RBT}^{\circledR}$ [23] when attempting to differentiate between an infection of short or long evolution, since infections of a long evolution may be indicative of focal brucellosis or a relapse of disease. This stage is typified by an absence of $\operatorname{IgM}$, an increase of $\operatorname{IgG}, \operatorname{IgA}$, and non-agglutinating antibodies [19,22].

The IgG Enzyme-linked Immunoassay (ELISA) ${ }^{\circledR}$ is recognised to be a very sensitive serological test for detecting antibodies of the IgG class, which are predominately found in long evolution brucellosis cases. However, available IgG ELISA ${ }^{\circledR}$ tests may have variable cut-offs due to the manufacturer differences and differences in brucellosis prevalence across areas and populations. An example of this can be found in the different cut-off reported in Hasibi et el. (2013) [24] and Peeridogaheh et al. (2013) [25].

The BrucellaCapt ${ }^{\circledR}$, a single step immunocapture assay, has been recommended to detect relapses of brucellosis or the disease in the long evolution of infection ("chronic" stage), because of its ability to detect non-agglutinating (blocking) or incomplete antibodies, which are dominant during this stage of infection [20]. The BrucellaCapt ${ }^{\circledR}$, similar to the $\mathrm{RBT}^{\circledR}$, also detects IgM, IgG, and IgA antibodies. It is commercially available, both cost effective and rapid and is reported to have a sensitivity of $99.2 \%$ and a specificity of $96 \%$, on samples determined positive by the Coomb's test [26]. Furthermore, BrucellaCapt ${ }^{\circledR}$ titres indicate the activity of infection regardless of the stage of disease, decreasing slowly after 
relapse and more distinctly after treatment [20]. However, BrucellaCapt ${ }^{\circledR}$ was developed to diagnose brucellosis in non-endemic countries, and therefore it is still necessary to adjust the recommended cut-off titre to detect clinical cases when used in an endemic area $[25,27]$.

There is little data on the prevalence of brucellosis in people in Africa [28]. The limited seroprevalence studies of brucellosis in humans in sub-Saharan Africa have targeted patients with fevers of unknown origin [29,30], abattoir workers [30] and the farming community and veterinarians [31-34]. However, no such study has been conducted in South Africa yet. In South Africa (SA), human brucellosis is a notifiable medical condition and bovine brucellosis is a controlled animal disease [35]. However, human brucellosis is suspected to be under detected and underdiagnosed in SA [36]. Transmission of Brucella to workers on farms that have brucellosis infected cattle herds is a known historical occupational hazard in the Gauteng region of SA [35,37], yet to date, no study has been conducted on cattle farms in SA to understand farm workers' or veterinary officials knowledge of brucellosis, or to identify risk factors for exposure or potentially undiagnosed clinical infection, amongst these workers on farms in Gauteng.

The objectives of this study were firstly to understand knowledge of brucellosis and health seeking response to brucellosis-like symptoms amongst workers on cattle farms, and secondly to identify risk factors for Brucella seropositivity in this group.

\section{Results}

A total of 230 individuals were tested. Seroprevalence in this group varied depending on the test used (Table 1).

Table 1. Seroprevalence amongst cattle handlers $(N=230)$ according to the Rose Bengal Test $(\mathrm{RBT})$,

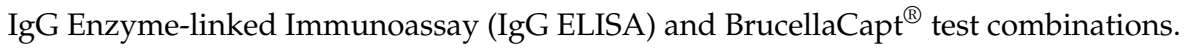

\begin{tabular}{cccc}
\hline & RBT $^{\circledR}$ & IgG ELISA $^{\circledR}$ & BrucellaCapt $^{\circledR}$ \\
\hline RBT $^{\circledR}$ & $10.1 \%(23 / 230)$ & - & - \\
IgG ELISA $^{\circledR}$ & $9.1 \%(21 / 230)$ & $20.9 \%(48 / 230)$ & - \\
BrucellaCapt $^{\circledR}$ & $6.1 \%(14 / 230)$ & $6.5 \%(15 / 230)$ & $6.5 \%(15 / 230)$ \\
\hline
\end{tabular}

Using different combinations of tests revealed a range of infection in the study group, from infection of a very short evolution $\left(\mathrm{RBT}^{\circledR}\right.$ and IgM ELISA ${ }^{\circledR}$ positive and IgG ELISA ${ }^{\circledR}$ negative) to infection of a long evolution (RBT ${ }^{\circledR}$ and IgM negative and BrucellaCapt ${ }^{\circledR}$ and IgG ELISA ${ }^{\circledR}$ positive) (Figure 1).

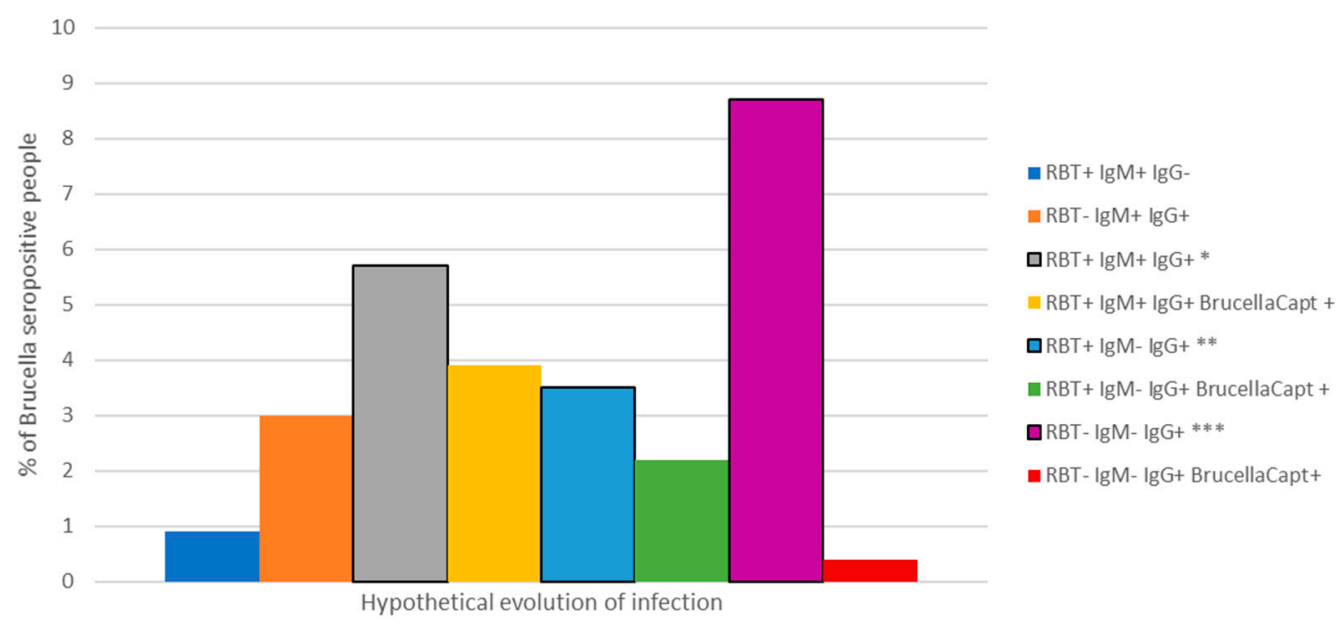

Figure 1. Seroprevalence and range of Brucella antibody profiles amongst study participants $(n=230)$, Gauteng, 2016. * Short evolution of infection, ${ }^{* *}$ Long evolution of infection, ${ }^{* * *}$ Exposure or inactive/resolved infection. 
Farm workers exposed to Brucella infected cattle herds (30 farms), made up 65\% $(150 / 230)$ of the sample whilst $23 \%$ (53/230) were farm workers exposed to Brucella seronegative herds (11 farms). The remaining $12 \%$ (27/230) were state veterinary officials who are routinely exposed to both seropositive and seronegative Brucella cattle herds although not necessarily on the farms where farm workers were tested.

Using tests individually, seroprevalence ranged from 3.9\% (BrucellaCapt ${ }^{\circledR}$ ) to $16.3 \%$ (IgG ELISA ${ }^{\circledR}$ ) amongst farm workers on case farms. On control farms, seroprevalence in farm workers ranged from $1.8 \%$ (BrucellaCapt $^{\circledR}$ ) to $5.5 \%$ (IgG ELISA ${ }^{\circledR}$ ). Amongst veterinary officials, seroprevalence ranged from $26.6 \%$ using either the $\mathrm{RBT}^{\circledR}$ or the BrucellaCapt ${ }^{\circledR}$, to $74.1 \%\left(\right.$ IgG ELISA $\left.{ }^{\circledR}\right)$.

Symptoms reported by BrucellaCapt ${ }^{\circledR}$ seropositive persons $(n=15)$ were distributed across titres and infection of both short and long evolution, with more symptoms being reported by those who had an antibody profile indicative of a long evolution infection (Table 2).

Table 2. Distribution of BrucellaCapt ${ }^{\circledR}$ titres and reported symptoms (within previous 6 months) over infection evolution $(n=15)$.

\begin{tabular}{|c|c|c|c|c|}
\hline Case & BrucellaCapt ${ }^{\circledR}$ Titre & Short Evolution ${ }^{*}$ & Long Evolution $^{* *}$ & Exposure/Inactive or Resolved Infection ${ }^{* * *}$ \\
\hline 1 & $1: 320$ & no symptoms & & \\
\hline 2 & $1: 320$ & no symptoms & & \\
\hline 3 & $1: 320$ & no symptoms & & \\
\hline 4 & $1: 320$ & joint pain & & \\
\hline 5 & $1: 320$ & fever & & \\
\hline 6 & $1: 320$ & & Fatigue & \\
\hline 7 & $1: 320$ & & & no symptoms \\
\hline 8 & $1: 640$ & no symptoms & & \\
\hline 9 & $1: 640$ & no symptoms & & \\
\hline 10 & $1: 640$ & & joint pain & \\
\hline 11 & $1: 640$ & & Fever & \\
\hline 12 & $1: 640$ & & Headache & \\
\hline 13 & $1: 640$ & & Fatigue & \\
\hline 14 & $1: 1280$ & headache & & \\
\hline 15 & $1: 2560$ & fever & & \\
\hline
\end{tabular}

The majority of BrucellaCapt ${ }^{\circledR}$ seropositive study participants (87\%) either did not visit a clinic in response to brucellosis-like symptoms, or they attended a medical facility but were not asked their occupational history by the attending doctor (Table 3 ).

Table 3. Possible undetected brucellosis cases amongst BrucellaCapt ${ }^{\circledR}$ seropositive study participants $(n=15)$.

\begin{tabular}{cccc}
\hline BrucellaCapt ${ }^{\circledR}$ Titres & $\begin{array}{c}\text { Self-Medicate/ } \\
\text { Do Nothing/Pray }\end{array}$ & $\begin{array}{c}\text { Visit Clinic/Private Medical Doctor/Hospital } \\
\text { Occupational History Taken by } \\
\text { Attending Medical Doctor }\end{array}$ \\
\hline $1: 320$ & 4 & 2 & 1 \\
$1: 640$ & 3 & 0 & 1 \\
$1: 1280$ & 1 & 1 & 0 \\
$1: 2560$ & 0 & $5(33 \%)$ & 0 \\
\hline Total & $8(53 \%)$ & $2(13 \%)$ \\
\hline
\end{tabular}

\subsection{Knowledge of Brucellosis and Health Seeking Behaviour for Brucellosis-Like Symptoms}

Cattle handler knowledge of brucellosis symptoms in cattle was low with $20.7 \%$ $(42 / 203)$ aware that $B$. abortus can cause abortions in cattle, can cause calves to be born weak and can also be in a herd without causing abortions. Whilst $36.9 \%(75 / 203)$ knew 
that bovine brucellosis can cause disease in people, only $16.3 \%(33 / 203)$ reported knowing the human symptoms of disease. In contrast $63.0 \%(17 / 27)$ of veterinary officials knew the symptoms of bovine brucellosis and $100 \%$ knew it to be a zoonotic disease, but only $89.0 \%(24 / 27)$ knew the symptoms of human disease. There was a significant difference in wanting more information on brucellosis, between farm workers on case farms $(\mathrm{OR}=2.5$, 95\% CI: 1.5-5.3, $p=0.019$ ) and veterinary officials (OR $=7.3,95 \%$ CI: $2.6-20.7, p<0.001$ ) vs. farm workers on control farms. Despite having greater awareness of the zoonotic nature of bovine brucellosis and human symptoms of the disease as well as wanting information more than farm workers, only $22.2 \%(6 / 27)$ of veterinary officials would opt to visit a clinic, doctor, or hospital in response to self-experienced brucellosis-like symptoms, compared to $74.9 \%(152 / 203)$ of farm workers $(p<0.001)$. We also found that $53.3 \%(8 / 15)$ of BrucellaCapt ${ }^{\circledR}$ seropositive people did not visit a clinic in response to brucellosis-like symptoms which may result in undetected cases of brucellosis. Further findings are summarised in Table 4.

Table 4. Distribution of responses to knowledge questions, amongst workers on cattle farms in, Gauteng, 2016.

\begin{tabular}{|c|c|c|c|c|c|c|c|c|}
\hline & \multicolumn{2}{|c|}{$\begin{array}{l}\text { Farm Workers } \\
\text { Exposed to Brucella } \\
\text { Seropositive Cattle } \\
\text { Herds }(n=150)\end{array}$} & \multicolumn{2}{|c|}{$\begin{array}{c}\text { Farm Workers } \\
\text { Handling Brucella } \\
\text { Seronegative Cattle } \\
\text { Herds }(n=53)\end{array}$} & \multicolumn{2}{|c|}{$\begin{array}{c}\text { Veterinary Officials } \\
\text { Exposed to Brucella } \\
\text { Seropositive and } \\
\text { Seronegative Herds }(n=27)\end{array}$} & \multicolumn{2}{|c|}{$\begin{array}{c}\text { Total } \\
(N=230)\end{array}$} \\
\hline & $n$ & $\%$ & $n$ & $\%$ & $n$ & $\%$ & $n$ & $\%$ \\
\hline \multicolumn{9}{|l|}{ "Do you know the symptoms of brucellosis in cattle?" } \\
\hline No & 112 & 74.7 & 41 & 77.4 & 10 & 37.0 & 163 & 70.9 \\
\hline Yes & 38 & 25.3 & 12 & 22.6 & 17 & 63.0 & 67 & 29.1 \\
\hline Verified Yes & 30 & 20 & 12 & 22.6 & 17 & 63.0 & & \\
\hline \multicolumn{9}{|l|}{ "Do you know the symptoms of brucellosis in people?" } \\
\hline No & 129 & 86.0 & 41 & 77.4 & 3 & 11.1 & 173 & 75.2 \\
\hline Yes & 21 & 14.0 & 12 & 22.6 & 24 & 88.9 & 57 & 24.8 \\
\hline \multicolumn{9}{|l|}{ "Do you understand how brucellosis causes a drop in profit?" } \\
\hline No & 115 & 76.7 & 39 & 73.6 & 0 & 0.0 & 154 & 67.0 \\
\hline Yes & 35 & 23.3 & 14 & 26.4 & 27 & 100.0 & 76 & 33.0 \\
\hline \multicolumn{9}{|l|}{ “Do you know how brucellosis can reduce your ability to work?" } \\
\hline No & 120 & 80.0 & 40 & 75.5 & 6 & 22.2 & 166 & 72.2 \\
\hline Yes & 30 & 20.0 & 13 & 24.5 & 21 & 77.8 & 64 & 27.8 \\
\hline \multicolumn{9}{|l|}{ "Drinking raw milk is safe and healthy" } \\
\hline Do not know & 14 & 9.3 & 0 & 0.0 & 0 & 0 & 14 & 6.1 \\
\hline No & 62 & 41.3 & 13 & 24.5 & 25 & 92.6 & 100 & 43.5 \\
\hline Yes & 74 & 49.3 & 40 & 75.5 & 2 & 7.4 & 116 & 50.4 \\
\hline \multicolumn{9}{|l|}{ "Brucellosis can cause abortions in cattle" } \\
\hline Do not know & 45 & 30.0 & 10 & 18.9 & 0 & 0.0 & 55 & 23.9 \\
\hline No & 42 & 28.0 & 26 & 49.1 & 1 & 3.7 & 69 & 30.0 \\
\hline Yes & 63 & 42.0 & 17 & 32.1 & 26 & 96.3 & 106 & 46.1 \\
\hline \multicolumn{9}{|l|}{ "Brucellosis can cause calves to be born weak" } \\
\hline Do not know & 49 & 32.7 & 10 & 18.9 & 1 & 3.7 & 60 & 26.1 \\
\hline No & 48 & 32.0 & 29 & 54.7 & 6 & 22.2 & 83 & 36.1 \\
\hline Yes & 53 & 35.3 & 14 & 26.4 & 20 & 74.1 & 87 & 37.8 \\
\hline \multicolumn{9}{|l|}{ "Brucellosis can be in the herd and not cause abortions" } \\
\hline Do not know & 50 & 33.3 & 10 & 18.9 & 2 & 7.4 & 54 & 23.5 \\
\hline No & 67 & 44.7 & 30 & 56.6 & 2 & 7.4 & 99 & 43.0 \\
\hline Yes & 33 & 22.0 & 13 & 24.5 & 23 & 85.2 & 69 & 30.0 \\
\hline \multicolumn{9}{|l|}{ "Brucellosis can cause disease in people" } \\
\hline Do not know & 45 & 30.0 & 11 & 20.8 & 0 & 0.0 & 49 & 21.3 \\
\hline No & 44 & 29.3 & 28 & 52.8 & 0 & 0.0 & 72 & 31.3 \\
\hline Yes & 61 & 40.7 & 14 & 26.4 & 27 & 100.0 & 102 & 44.3 \\
\hline \multicolumn{9}{|l|}{$\begin{array}{l}\text { Health seeking response to self-experienced brucellosis-like } \\
\text { symptoms }\end{array}$} \\
\hline Ignore symptoms, self-medicate, pray & 42 & 28.0 & 9 & 17.0 & 21 & 77.8 & 72 & 31.3 \\
\hline Visit clinic, doctor, or hospital & 108 & 72.0 & 44 & 83.0 & 6 & 22.2 & 158 & 68.7 \\
\hline \multicolumn{9}{|l|}{ Medical doctor asks occupational exposure history } \\
\hline Yes & 22 & 20.4 & 6 & 13.6 & 4 & 66.7 & 32 & 20.3 \\
\hline No & 86 & 79.6 & 38 & 86.4 & 2 & 33.3 & 126 & 79.7 \\
\hline \multicolumn{9}{|l|}{ What would you do if you observe a foetus in the field? } \\
\hline Report to farm manager, private or responsible state veterinarian & 103 & 68.7 & 14 & 26.4 & 26 & 96.3 & 143 & 62.2 \\
\hline Dispose of the foetus and do nothing more & 47 & 31.3 & 39 & 73.6 & 1 & 3.7 & 87 & 37.8 \\
\hline \multicolumn{9}{|l|}{ Would you like more information on brucellosis? } \\
\hline No & 95 & 63.3 & 43 & 81.1 & 10 & 37.0 & 148 & 64.3 \\
\hline Yes & 55 & 36.7 & 10 & 18.9 & 17 & 63.0 & 82 & 35.7 \\
\hline
\end{tabular}




\subsection{Univariable Analysis: Reported Brucellosis-Like Symptoms Associated with Evolution of Brucella Infection}

Univariable analysis of symptoms associated with infection of short evolution (RBT ${ }^{\circledR}$, IgM and IgG ELISA ${ }^{\circledR}$ seropositive), long evolution (IgM ELISA ${ }^{\circledR}$ seronegative and RBT $^{\circledR}$ and IgG ELISA ${ }^{\circledR}$ seropositive) and likely inactive infection (RBT ${ }^{\circledR}$ and IgM ELISA ${ }^{\circledR}$ seronegative and IgG ELISA ${ }^{\circledR}$ seropositive), identified a weak association between reported generalized aching and infection of short duration (OR $=4.8,95 \%$ CI: $0.4-27.9, p=0.103)$, and a suggestive stronger association between reported joint pain and infection of long duration $(\mathrm{OR}=5.1,95 \% \mathrm{CI}: 0.9-33.3, p=0.030)$. The distribution of symptoms across these stages of infection evolution and the associated significance, is shown in Table 5.

Table 5. Univariable analysis of Brucella antibody expression along the evolution of infection and brucellosis-like symptoms reported by farm workers and veterinary officials within the 6 months prior to the study, Gauteng, 2016.

\begin{tabular}{|c|c|c|c|c|c|c|c|c|c|c|}
\hline \multirow{2}{*}{$\begin{array}{l}\text { Symptoms within } \\
\text { Previous } 6 \text { Months }\end{array}$} & \multirow{2}{*}{$\begin{array}{l}\text { Study Participants } \\
\qquad(N=230)\end{array}$} & \multicolumn{3}{|c|}{ Short Evolution * } & \multicolumn{3}{|c|}{ Long Evolution ${ }^{* *}$} & \multicolumn{3}{|c|}{ Exposure/Inactive or Resolved Infection ${ }^{* * *}$} \\
\hline & & $n$ & $\%$ & $p$-Value & $n$ & $\%$ & $p$-Value & $n$ & $\%$ & $p$-Value \\
\hline Generalized aching & & & & 0.103 & & & 1 & & & 0.212 \\
\hline No & 220 & 11 & 5.0 & & 8 & 3.6 & & 18 & 8.2 & \\
\hline Yes & 10 & 2 & 20.0 & & 0 & 0 & & 2 & 20.0 & \\
\hline Joint pain & & & & 1 & & & 0.030 & & & 1 \\
\hline No & 170 & 10 & 5.9 & & 3 & 1.8 & & 15 & 8.8 & \\
\hline Yes & 60 & 3 & 5.0 & & 5 & 8.3 & & 5 & 8.3 & \\
\hline Fever & & & & 0.466 & & & 0.357 & & & 0.755 \\
\hline No & 191 & 10 & 5.2 & & 8 & 4.2 & & 16 & 8.4 & \\
\hline Yes & 39 & 3 & 7.7 & & 0 & 0 & & 4 & 10.3 & \\
\hline Sweating & & & & 0.698 & & & 0.362 & & & 1 \\
\hline No & 194 & 12 & 6.2 & & 8 & 4.1 & & 17 & 8.8 & \\
\hline Yes & 36 & 1 & 2.8 & & 0 & 0 & & 3 & 8.3 & \\
\hline Night-Sweating & & & & 0.475 & & & 0.357 & & & 1 \\
\hline No & 190 & 12 & 6.3 & & 8 & 4.2 & & 17 & 8.9 & \\
\hline Yes & 40 & 1 & 2.5 & & 0 & 0 & & 3 & 7.5 & \\
\hline Fatigue & & & & 0.434 & & & 0.614 & & & 0.747 \\
\hline No & 194 & 10 & 5.2 & & 6 & 3.1 & & 18 & 9.3 & \\
\hline Yes & 36 & 3 & 8.3 & & 2 & 5.6 & & 2 & 5.6 & \\
\hline Headache & & & & 0.538 & & & 0.109 & & & 1 \\
\hline No & 161 & 8 & 5.0 & & 8 & 5.0 & & 14 & 8.7 & \\
\hline Yes & 69 & 5 & 7.2 & & 0 & 0 & & 6 & 8.7 & \\
\hline Anorexia & & & & 1 & & & 0.303 & & & 1 \\
\hline No & 220 & 13 & 5.9 & & 7 & 3.2 & & 20 & 9.1 & \\
\hline Yes & 10 & 0 & 0 & & 1 & 10.0 & & 0 & 0 & \\
\hline Weight loss & & & & 1 & & & 1 & & & 0.637 \\
\hline No & 214 & 12 & 5.6 & & 8 & 3.7 & & 18 & 8.4 & \\
\hline Yes & 16 & 1 & 6.3 & & 0 & 0 & & 2 & 12.5 & \\
\hline
\end{tabular}

\subsection{Univariable and Multivariable Analysis of Risk Factors Associated with Evolution of} Brucella Infection

\subsubsection{Short Evolution $\left(\mathrm{RBT}^{\circledR}, \operatorname{IgM}\right.$ IgG ELISA ${ }^{\circledR}$ Seropositive)}

Univariable analysis of factors associated with infection of a short evolution identified worker group, handling of afterbirth or placenta, vaccinating cattle with RB51/S19 and slaughter of cattle, for inclusion into the multivariable logistic regression model at significance $p<0.2$ (Table 6). The handling of afterbirth or placenta was marginally significant $(\mathrm{OR}=8.9,95 \% \mathrm{CI}: 1.0-81.1, p=0.052)$ and slaughter of cattle significant $(\mathrm{OR}=5.3,95 \% \mathrm{CI}$ : $1.4-19.6, p=0.013)$ in the mixed effects logistic regression model fit for $\left(\mathrm{RBT}^{\circledR}\right.$, IgM ELISA $^{\circledR}$ and IgG ELISA ${ }^{\circledR}$ ) seropositivity amongst persons tested. The random effect of clustering at farm level was not significant $(p=0.2137)$ with an intraclass correlation (ICC) of $0.16(95 \%$ CI: 0.01-0.85). 
Table 6. Uni- and multivariable analysis of factors associated with Brucella infection of a short evolution (RBT ${ }^{\circledR}$, IgM ELISA ${ }^{\circledR}$ and IgG ELISA ${ }^{\circledR}$ seropositivity) amongst farm worker and veterinary officials in Gauteng, 2016.

\begin{tabular}{|c|c|c|c|c|c|c|c|}
\hline \multirow{3}{*}{ Variable and Level } & \multirow{3}{*}{$\begin{array}{l}\text { Study Participants } \\
\qquad(N=230)\end{array}$} & \multicolumn{3}{|c|}{ Univariable Analysis } & \multirow{2}{*}{\multicolumn{3}{|c|}{ Multivariable Analysis }} \\
\hline & & \multicolumn{2}{|c|}{ Short Evolution } & \multirow{2}{*}{$p$-Value } & & & \\
\hline & & $n$ & $\%$ & & Odds Ratio & $95 \% \mathrm{CI}$ & $p$-Value \\
\hline Worker group & & & & 0.089 & & & \\
\hline Farm Workers exposed to Brucella non-reactor & 53 & 1 & 1.9 & & & & \\
\hline Farm Workers exposed to Brucella reactor herds & 150 & 9 & 6 & & & & \\
\hline Veterinary officials & 27 & 3 & 11.1 & & & & \\
\hline Duration of occupation & & & & 0.286 & & & \\
\hline$<2 y$ & 63 & 1 & 1.6 & & & & \\
\hline $2-6 y$ & 59 & 4 & 6.8 & & & & \\
\hline$>6-14 y$ & 54 & 5 & 9.3 & & & & \\
\hline$>14 \mathrm{y}$ & 54 & 3 & 5.6 & & & & \\
\hline Brucellosis-like symptoms & & & & 0.567 & & & \\
\hline None & 100 & 7 & 7 & & & & \\
\hline 1 or more & 130 & 6 & 4.6 & & & & \\
\hline Health seeking behaviour & & & & 0.551 & & & \\
\hline Self-medicate/do nothing/pray & 72 & 5 & 6.9 & & & & \\
\hline Visit doctor/clinic & 158 & 8 & 5.1 & & & & \\
\hline Drink Unpasteurized milk & & & & 1 & & & \\
\hline No & 111 & 6 & 5.4 & & & & \\
\hline Yes & 119 & 7 & 5.9 & & & & \\
\hline Handle cows at calving & & & & 0.236 & & & \\
\hline No & 73 & 2 & 2.7 & & & & \\
\hline Yes & 157 & 11 & 7 & & & & \\
\hline Handle placenta or afterbirth & & & & 0.020 & & & \\
\hline No & 87 & 1 & 1.1 & & 1 & - & - \\
\hline Yes & 143 & 12 & 8.4 & & 8.9 & $1.0-81.1$ & 0.052 \\
\hline Handle newborn calves & & & & 1 & & & \\
\hline No & 71 & 4 & 5.6 & & & & \\
\hline Yes & 159 & 9 & 5.6 & & & & \\
\hline Vaccinate cattle (S19/RB51) & & & & 0.151 & & & \\
\hline No & 103 & 3 & 2.9 & & & & \\
\hline Yes & 127 & 10 & 7.9 & & & & \\
\hline Milk cows & & & & 0.561 & & & \\
\hline No & 144 & 7 & 4.9 & & & & \\
\hline Yes & 86 & 6 & 7.0 & & & & \\
\hline Slaughter cattle & & & & 0.007 & & & \\
\hline No & 169 & 5 & 3.0 & & 1 & - & - \\
\hline Yes & 61 & 8 & 13.1 & & 5.3 & $1.4-19.6$ & 0.013 \\
\hline
\end{tabular}

\subsubsection{Long Evolution (RBT ${ }^{\circledR}, \operatorname{IgG}$ ELISA ${ }^{\circledR}$ Positive and IgM ELISA ${ }^{\circledR}$ Negative)}

Farm workers exposed to case herds and veterinary officials compared to those exposed to seronegative herds in the exposure group variable, increasing duration of occupational exposure, and handling new-born calves were associated with infection of a long evolution $(p<0.02)$ in the univariable analysis and were included in the mixed effect multivariable logistic regression model.

In the mixed effects multivariable logistic regression model (Table 7), veterinary officials compared to farm workers exposed to seropositive herds (OR $=59.2,95 \% \mathrm{CI}$ : $1.0-3445.9, p=0.049)$, was identified as marginally significant, although the small number of events of this outcome increases the uncertainty of this confidence interval. This result should therefore be interpreted with caution. The random effect of clustering at farm level was significant (LR test vs. logistic model: chibar2 $=4.68, p=0.015$ ) with an ICC of 0.51 (95\% CI: $0.14-0.88$ ). The clustering identifies that $3 / 5$ veterinary officials in this group, were from the Germiston State Vet area. The Wald Chi2 statistic for the mixed effects model (3.88) was also marginally significant $(p=0.049)$. 
Table 7. Uni- and multivariable analysis of factors associated with RBT $^{\circledR}, \operatorname{IgG}$ ELISA $^{\circledR}$ positive and IgM ELISA ${ }^{\circledR}$ negative farm workers and veterinary officials in Gauteng, 2016.

\begin{tabular}{|c|c|c|c|c|c|c|c|}
\hline \multirow{3}{*}{ Variable and Level } & \multirow{3}{*}{$\begin{array}{l}\text { Study Participants } \\
\qquad(N=230)\end{array}$} & \multicolumn{3}{|c|}{ Univariable Analysis } & \multirow{2}{*}{\multicolumn{3}{|c|}{ Multivariable Analysis }} \\
\hline & & \multicolumn{2}{|c|}{ Long Evolution } & \multirow{2}{*}{$p$-Value } & & & \\
\hline & & $n$ & $\%$ & & Odds Ratio & $95 \%$ CI & $p$-Value \\
\hline Exposure Group & & & & 0.001 & & & \\
\hline Farm workers exposed to Brucella non-reactor herds & 53 & 0 & 0 & & - & - & - \\
\hline Farm workers exposed to Brucella reactor herds & 150 & 3 & 2.0 & & 1 & - & - \\
\hline Veterinary officials & 27 & 5 & 18.5 & & 59.2 & $1.0-3445.9$ & 0.049 \\
\hline Duration of occupation & & & & 0.017 & & & \\
\hline$\leq 2 \mathrm{y}$ & 63 & 0 & 0 & & & & \\
\hline $2-6 y$ & 58 & 1 & 1.7 & & & & \\
\hline$>6-14$ y & 52 & 2 & 3.8 & & & & \\
\hline$>14 \mathrm{y}$ & 49 & 5 & 10.2 & & & & \\
\hline Brucellosis-like symptoms & & & & 0.142 & & & \\
\hline None & 100 & 1 & 1.0 & & & & \\
\hline 1 or more & 130 & 7 & 5.4 & & & & \\
\hline Health seeking behaviour & & & & 0.262 & & & \\
\hline Self-medicate/do nothing/pray & 72 & 4 & 5.6 & & & & \\
\hline Visit doctor/clinic & 158 & 4 & 2.5 & & & & \\
\hline Drink unpasteurized milk & & & & 0.003 & & & \\
\hline No & 111 & 8 & 7.2 & & & & \\
\hline Yes & 119 & 0 & 0 & & & & \\
\hline Handle cows at calving & & & & 0.268 & & & \\
\hline No & 73 & 4 & 5.5 & & & & \\
\hline Yes & 157 & 4 & 2.5 & & & & \\
\hline Handle placenta or afterbirth & & & & 0.481 & & & \\
\hline No & 87 & 4 & 4.6 & & & & \\
\hline Yes & 143 & 4 & 2.8 & & & & \\
\hline Handle newborn calves & & & & 0.111 & & & \\
\hline No & 71 & 5 & 7.0 & & & & \\
\hline Yes & 159 & 3 & 1.9 & & & & \\
\hline Vaccinate cattle (S19/RB51) & & & & 0.302 & & & \\
\hline No & 103 & 2 & 1.9 & & & & \\
\hline Yes & 127 & 6 & 4.7 & & & & \\
\hline Milk cows & & & & 0.713 & & & \\
\hline No & 144 & 6 & 4.2 & & & & \\
\hline Yes & 86 & 2 & 2.3 & & & & \\
\hline Slaughter cattle & & & & 0.440 & & & \\
\hline No & 169 & 5 & 3.0 & & & & \\
\hline Yes & 61 & 3 & 4.9 & & & & \\
\hline
\end{tabular}

2.3.3. Exposure/Inactive or Resolved Infection $\left(\mathrm{RBT}^{\circledR}{ }^{\circledR}\right.$ IgM ELISA $^{\circledR}$ Seronegative and IgG ELISA $^{\circledR}$ Seropositive)

In the univariable analysis of factors associated with likely exposure/inactive or resolved infection (RBT ${ }^{\circledR}$ and IgM ELISA ${ }^{\circledR}$ seronegative and IgG ELISA ${ }^{\circledR}$ seropositive), there was evidence of an association between the outcome and self-medicating, praying, or ignoring brucellosis-like symptoms in this group compared to those who seek out medical attention in response to symptoms. Seropositive people in this group were associated with not being engaged in the following risk activities: handling cattle at calving, handling afterbirth or placenta, handling new-born calves and milking cows. Altogether seven variables $(p<0.20)$ were identified for inclusion into the multivariable model (Table 8 ).

The only variable remaining associated with seropositivity in this group was veterinary officials compared to those exposed to seropositive herds in the exposure group veterinary ( $\mathrm{OR}=7.0,95 \% \mathrm{CI}: 2.4-20.2, p<0.001)$, whilst there was strong evidence of an association between the handling of afterbirth or placenta and seronegative people in this group (OR $=3.9,95 \%$ CI: $1.3-11.3, p=0.012)$. This is to be expected given that the above finding that the handling of placenta and after birth was associated with people who were $\mathrm{RBT}^{\circledR}$, IgM and IgG ELISA ${ }^{\circledR}$ seropositive (short evolution infection) (Table 6). The random effect of clustering at farm level was non-significant and the ICC $9.04 \times 10^{-34}$. The Wald Chi2 statistic for the mixed effects model (16.77) was significant $(p<0.001)$. 
Table 8. Uni- and multivariable analysis of factors associated with RBT $^{\circledR}, \operatorname{IgM}_{\text {ELISA }}{ }^{\circledR}$ seronegative and IgG ELISA ${ }^{\circledR}$ seropositive reactors amongst farm workers and veterinary officials in Gauteng, 2016.

\begin{tabular}{|c|c|c|c|c|c|c|c|}
\hline \multirow{3}{*}{ Variable and Level } & \multirow{3}{*}{$\begin{array}{l}\text { Study Participants } \\
\qquad(N=230)\end{array}$} & \multicolumn{3}{|c|}{ Univariable Analysis } & \multirow{2}{*}{\multicolumn{3}{|c|}{ Multivariable Analysis }} \\
\hline & & \multicolumn{2}{|c|}{ Exposure/Inactive or Resolved } & \multirow{2}{*}{$p$-Value } & & & \\
\hline & & $n$ & $\%$ & & Odds Ratio & $95 \% \mathrm{CI}$ & $p$-Value \\
\hline Exposure Group & & & & $<0.001$ & & & \\
\hline $\begin{array}{l}\text { Farm workers exposed to Brucella } \\
\text { non-reactor herds }\end{array}$ & 53 & 0 & 0 & & - & - & - \\
\hline $\begin{array}{l}\text { Farm workers exposed to Brucella } \\
\text { reactor herds }\end{array}$ & 150 & 11 & 7.3 & & 1 & - & - \\
\hline Veterinary officials & 27 & 9 & 33.3 & & 7.0 & $2.4-20.3$ & $<0.001$ \\
\hline Duration of occupation & & & & 0.005 & & & \\
\hline$\leq 2 \mathrm{y}$ & 61 & 2 & 3.3 & & & & \\
\hline $2-6 y$ & 56 & 3 & 5.4 & & & & \\
\hline$>6-14$ y & 49 & 5 & 10.2 & & & & \\
\hline$>14 \mathrm{y}$ & 44 & 10 & 22.7 & & & & \\
\hline Brucellosis-like symptoms & & & & 0.486 & & & \\
\hline None & 100 & 7 & 6.0 & & & & \\
\hline 1 or more & 130 & 13 & 10.0 & & & & \\
\hline Health seeking behaviour & & & & 0.010 & & & \\
\hline Self-medicate/do nothing/pray & 72 & 12 & 16.7 & & & & \\
\hline Visit doctor/clinic & 158 & 8 & 5.1 & & & & \\
\hline Drink unpasteurized milk & & & & 1 & & & \\
\hline No & 111 & 10 & 9.0 & & & & \\
\hline Yes & 119 & 10 & 8.4 & & & & \\
\hline Handle cows at calving & & & & 0.010 & & & \\
\hline No & 73 & 12 & 16.4 & & & & \\
\hline Yes & 157 & 8 & 5.1 & & & & \\
\hline Handle placenta or afterbirth & & & & 0.003 & & & \\
\hline No & 87 & 14 & 16.1 & & 1 & - & - \\
\hline Yes & 143 & 6 & 4.2 & & 0.3 & $0.1-0.7$ & 0.012 \\
\hline Handle newborn calves & & & & 0.005 & & & \\
\hline No & 71 & 12 & 16.9 & & & & \\
\hline Yes & 159 & 8 & 5.0 & & & & \\
\hline Vaccinate cattle (S19/RB51) & & & & 0.239 & & & \\
\hline No & 103 & 6 & 5.8 & & & & \\
\hline Yes & 127 & 14 & 11.0 & & & & \\
\hline Milk cows & & & & 0.031 & & & \\
\hline No & 144 & 17 & 11.8 & & & & \\
\hline Yes & 86 & 3 & 3.5 & & & & \\
\hline Slaughter cattle & & & & 0.603 & & & \\
\hline No & 169 & 16 & 9.5 & & & & \\
\hline Yes & 61 & 4 & 6.6 & & & & \\
\hline
\end{tabular}

\section{Discussion}

This study identified a gap in cattle handler knowledge of brucellosis symptoms in cattle and people and identified symptoms and risk factors associated with infection of short and long evolution and likely inactive/resolved infection or exposure.

Overall cattle handler knowledge of brucellosis symptoms in cattle (29.1\%) was similar to a recent global pooled awareness estimate $(28.4 \%)$ for knowledge of animal symptoms of brucellosis [38], and marginally higher than the one found amongst cattle keepers $(22.6 \%)$ in the Eastern Cape (E. Cape) of SA [39]. In contrast, cattle handler knowledge of brucellosis symptoms in people in this study $(25 \%)$, was much lower than the global statistic (41\%) [38] but higher than the one (12.7\%) found in the E. Cape study [39]. Differences between the global and local proportions of awareness of human brucellosis symptoms, may be attributed to both SA studies selecting workers cattle farms. A significant source of knowledge for this group are the veterinary officials [39] whose main task is to increase cattle keepers' knowledge of the livestock disease. The difference between cattle handler knowledge of human symptoms of brucellosis in the E. Cape study and this study, may be partially explained by greater awareness amongst veterinary officials $(88.9 \%)$ who formed part of this study group as opposed to only farm workers (16.3\%) in this study.

The significant difference in wanting more information on brucellosis, between farm workers on case farms, veterinary officials and farm workers on control farms was unex- 
pected and needs to be investigated further. A possible explanation may be that veterinary officials perceived themselves to be at greater risk than farm workers or began to believe themselves to be susceptible to brucellosis. Such belief is a key construct in the health belief model of health seeking behaviour [40], triggering a drive for more information. It is also likely that exposure to the questionnaire made them realise that despite knowing brucellosis to be a zoonotic disease, they did not know the symptoms of human disease which has a direct effect on their own health, well-being, and occupational safety.

Farm workers' and cattle keepers' health seeking behaviour in response to brucellosislike symptoms also varied between provinces. In the E. Cape, $93.2 \%$ of farm workers and cattle keepers' reported that they would go to a clinic in response to brucellosis-like symptoms experienced [39], as opposed to $68.7 \%$ in this study. The difference between farm workers and veterinary officials' attitudes toward experiencing brucellosis-like symptoms in themselves with only $22 \%$ of veterinary officials seeking out medical care in response to brucellosis-like symptoms, is a finding of concern and needs further investigation by occupational health and safety officers.

The importance of seeking out medical care in these occupational groups is highlighted by finding that $7 / 15$ of those that tested seropositive on the BrucellaCapt ${ }^{\circledR}$ would not seek out medical care in response to brucellosis-like symptoms. It has been documented that brucellosis cases delay presenting to a medical facility from the onset of symptoms with a median delay time of 90 days [41]. Such delays increase the likelihood of complicated brucellosis, treatment failure and chronic brucellosis [6]. These findings may also suggest lack of awareness amongst medical clinicians of the occupational risk of brucellosis to farm workers and veterinary officials, which has been highlighted as a matter of concern in SA $[35,36]$.

In this study, different risk factors were found to be associated with different serological tests combinations selected to detect infection of short and long evolution. We identified that the handling of afterbirth or placenta to be marginally significant and slaughter of cattle significantly associated with infection of a short evolution whilst infection of a long evolution was weakly associated with being a veterinary official compared to farm workers. Veterinary officials compared to farm workers were associated with inactive/resolved infection or exposure. Farm workers without this serological outcome were significantly associated with afterbirth or placenta. This is to be expected given that the above finding that the handling of placenta and after birth was associated with people who were RBT $^{\circledR}$, $\operatorname{IgM}$ and IgG ELISA ${ }^{\circledR}$ seropositive (short evolution infection). Negligible clustering at farm level was evident amongst exposed or inactive/resolved infection cases, with slight clustering amongst short evolution cases and greatest clustering amongst the long evolution of infection cases. This effect can be partially explained by the presence of different categories of occupationally exposed persons in this sample. This also contributed to separation in the data, wide confidence intervals and large odds ratios which were compounded by the small number of events of seropositivity. These limitations are not uncommon and has been reported and discussed in literature. For example, in a similar study conducted, Rahman et. al. (2012) caution on the interpretation of odds ratios and confidence intervals calculated from a sample not representative of occupationally exposed persons or of insufficient size [16].

Despite this problem, these findings may be suggesting that those farm workers engaged in the slaughter of cattle were more recently exposed as opposed to those who routinely handle afterbirth or placenta. Alternatively, for slaughter of cattle there could be a recall bias as people refer to the last months rather to the last years and therefore it may not appear to be a risk factor for IgG seropositivity. Regardless, this finding indicates the importance of selecting and using appropriate screening tests in Gauteng, to determine the seroprevalence of Brucella amongst farm workers in bovine brucellosis endemic areas.

Veterinary officials are more regularly and frequently exposed to RB51 and S19 vaccination, as this is a fundamental bovine brucellosis control activity. Accidental exposure to RB51 through needlestick injury has been implicated as one of the main causes of 
brucellosis in veterinarians and their assistants [42,43]. Occupational risk to abattoir workers [33] and veterinarians has been well documented [28,44-48]. In this study, all the veterinary officials that tested seropositive were para-veterinarians, also known as animal health technicians, employed by the Government to perform selected veterinary services. Transmission of Brucella at the cattle-human-interface to officials in this context can occur through accidental self-inoculation whilst vaccinating cattle with S19 or RB51 vaccine, both of which are attenuated strains of B. abortus [49]. It may also occur during the collection of blood or milk samples for routine regulatory herd testing from farms participating in the provincial state veterinary services' bovine brucellosis control programme between 2014 and 2016. Furthermore, at least 50\% of AHTs reported assisting cattle with [50] dystocia, which may present a further route of transmission and exposure. Further investigation is needed to determine and mitigate the role of these variables in AHT exposure to Brucella on cattle farms.

The presence of significant risk factors and symptoms associated with infection of short and long evolution and poor health seeking behaviour in response to brucellosislike symptoms among farm workers and veterinary officials with these antibody profiles, strongly suggest the presence of undetected cases of human brucellosis on cattle farms.

\section{Materials and Methods}

\subsection{Ethical Considerations}

Ethical approval for the study was granted by the Research Ethics Committee, Faculty of Health Sciences, University of Pretoria (74/2015) and the Animal Ethics committee of the University of Pretoria (V011-16). All persons were informed about the objectives of the study and counselled prior to consent on the significance of a positive test result by the medical doctor on the team. All participants were telephonically informed of their result. Reactors were revisited and further counselled on the interpretation and implication of their seropositive result. Each reactor was also given a referral letter for their doctor's attention. This letter gave background on the study, a brief review of brucellosis and suggestions for follow-up, confirmation of disease and management of brucellosis patients to ensure the doctor was sufficiently capacitated to manage the patient.

\subsection{Study Area and Participants}

The study was conducted in Gauteng, the smallest of South Africa's nine provinces with an area of $18,176 \mathrm{~km}^{2}$. In total, 41 cattle herds, participating in the Provincial Veterinary Services voluntary bovine brucellosis control programme between 2014-2016, were selected for the study using a non-probabilistic sampling strategy [51]. Of these, 30 met the definition of a case farm: "a herd with two or more cattle testing seropositive on the Rose Bengal test $\left(\mathrm{RBT}^{\circledR}\right)$ and the complement fixation test $(\mathrm{CFT})$ at a reaction greater than or equal to $60 \mathrm{IU} / \mathrm{mL}^{\prime \prime}$. These herds were prioritized and purposively selected to increase the probability of detecting recent exposure to Brucella amongst workers on cattle farms. Eleven herds were classified as control herds: "a cattle herd with a laboratory-confirmed seronegative test between 2014-2016 and no history of a seropositive herd test during 1990 to 2014". Verification of case and control classifications was performed by cross-checking case herd records, reported by the State Veterinarians, with the Provincial Veterinary Services' Animal Health directorate in the annual Animal Health reports.

Selection criteria for eligibility to participate in this study was occupational contact with these cattle herds.

\subsection{Data and Sample Collection}

A multidisciplinary team comprising a veterinarian, medical doctor and animal health technician visited each farm. The animal health technician served as the translator, if and when needed, and was therefore, pre-trained on the administration of the questionnaire. The veterinarian administered the questionnaire whilst the medical doctor collected blood samples from the study participants. The sampling of veterinary officials took place at the 
veterinary offices on appointed days for each State Vet Area. Five millilitres of blood from each participant was drawn into two tubes: (1) clot activator without serum separation and (2) EDTA anticoagulant tube. Blood samples were transported on ice, respecting the biosecurity regulations for human samples transport, to the National Institute for Communicable Diseases, Centre for Emerging Zoonotic and Parasitic Diseases Unit by the medical doctor following the farm visit, for further processing.

\subsection{Study Design}

This study was a pilot study designed as a cross-sectional survey of workers on the selected cattle farms. All farm workers present on a farm on the day of testing were included in the sample $(n=203)$. The study was conducted on the farm sites between March and November 2016.

In addition to the farm workers, a subset of veterinary officials $(n=27)$ was included in the sample. These officials provide different services to farmers participating in the provincial bovine brucellosis control programme. Veterinary officials participating in this study was a voluntary sample of those who routinely collect blood samples and vaccinate cattle herds, vaccinate cattle without collecting blood samples, provide advisory services to cattle farmers without performing vaccinations or testing or perform diagnostic and clinical services on individual cattle. Only those veterinary officials volunteering to participate and who were available on the allocated day for testing were included in this study.

Structured questionnaires were used to collect information on risk factors for cattle handler and veterinary officials' exposure, knowledge and health seeking response to brucellosis-like symptoms brucellosis. The questionnaire was piloted on farm workers on two farms and questions clarified from feedback gained during the pilot. Participants in the pilot study were included in the sample. All farm workers were screened on the farms using commercially available kits from Vircell Granada Spain, for the RBT ${ }^{\circledR}$ [23], IgG ELISA $^{\circledR}[52,53]$, BrucellaCapt ${ }^{\circledR}[54,55]$ and IgM ELISA ${ }^{\circledR}[56]$ according to the manufacturers' instructions and results were interpreted according to the kit guidelines. Reported sensitivity and specificity for each test is shown below (Table 9).

Table 9. Reported sensitivity and specific of tests used $[23,52,54,56]$.

\begin{tabular}{ccc}
\hline Test Kit (Manufacturer Vircell) & Sensitivity & Specificity \\
\hline RBT $^{\circledR *}$ & $99.0 \%$ & $97.6 \%$ \\
IgM ELISA $^{\circledR * *}$ & $89.0 \%$ & $100 \%$ \\
IgG ELISA $^{\circledR * *}$ & $98.0 \%$ & $100 \%$ \\
BrucellaCapt $^{\circledR * *}$ & $95.1 \%$ & $99.0 \%$ \\
\hline
\end{tabular}

${ }^{*}$ Measured against another commercial Rose Bengal Card Kit; ${ }^{* *}$ Measured against Coomb's test.

For the $\mathrm{RBT}^{\circledR}$ test, all reagents were brought to room temperature and the antigen suspension carefully shaken. A total of $40 \mu \mathrm{L}$ of sample, $40 \mu \mathrm{L}$ of the positive and negative control were dispensed onto the individual circles of the test kit cards. One drop of the Rose Bengal-stained Brucella suspension was added close to the sample or control being analysed. The kit provided $5 \mathrm{~mL}$ of an acid-suspension of inactivated Brucella abortus antigen stained with Rose Bengal, containing phenol (concentration $<1 \%$ ). Both drops were mixed until all circle surfaces were covered. The card was carefully shaken for $4 \mathrm{~min}$, followed by reading of the wells for the presence or absence of agglutination.

For the IgG ELISA ${ }^{\circledR}, 100 \mu \mathrm{L}$ of serum diluent was added to each well. A total of $5 \mu \mathrm{L}$ of each sample, $5 \mu \mathrm{L}$ of positive and $5 \mu \mathrm{L}$ negative controls, with optical density (O.D.) of positive and negative controls being $>0.9$ and $<0.55$ respectively, and $5 \mu \mathrm{L}$ of cut off control was added to the corresponding wells and shaken on a plate shaker for $2 \mathrm{~min}$. The plate was then incubated for $45 \mathrm{~min}$ at $37 \pm 1{ }^{\circ} \mathrm{C}$ for $30 \mathrm{~min}$, after which excess liquid was aspirated from all wells and the wells washed 5 times with $0.3 \mathrm{~mL}$ of washing solution per well. Remaining liquid was drained away and $100 \mu \mathrm{L}$ of substrate solution immediately added into each well, after which the plate was incubated at room temperature for $20 \mathrm{~min}$. 
After this period, $50 \mu \mathrm{L}$ of stopping solution was added into all wells. Spectrophotometer readings at $450 / 620 \mathrm{~nm}$ were taken within $1 \mathrm{~h}$ of stopping. The mean O.D. for the cut off control was $[(<0.7 \times($ positive control O.D. $)+>1.5 \times($ negative control O.D. $)) / 2]$. The antibody index was calculated as [(sample O.D./cut off serum mean O.D.) $\times 10]$. Samples were classified as negative, equivocal, or positive if the antibody index was $<9,9-11$, and $>11$, respectively. The IgM ELISA ${ }^{\circledR}$ was conducted, and results interpreted in a similar manner as the IgG ELISA ${ }^{\circledR}$, except for the initial preparation of the wells, which required $25 \mu \mathrm{L}$ of human IgG sorbent to be added to each well to remove excess IgG antibodies or rheumatoid factor.

The BrucellaCapt ${ }^{\circledR}$ test was carried out as follows: all reagents were brought to room temperature before use. A total of $50 \mu \mathrm{L}$ of serum diluent was added into Well $\mathrm{A}$, after which $50 \mu \mathrm{L}$ of serum diluent was added into all wells (A-H). A total of $5 \mu \mathrm{L}$ of each serum, negative and positive control were added to Well A. Doubling dilutions with $50 \mu \mathrm{L}$ of each well was made from A to $\mathrm{H}$. A total of $50 \mu \mathrm{L}$ of the provided bacterial suspension (well homogenized by prior vigorous shaking) was added into all wells. Wells were sealed with adherent tape and incubated for $24 \mathrm{~h}$ at $37^{\circ} \mathrm{C}$ in a chamber. Titre results were read after this and interpreted as follows: Row A-1:40, Row B-1:80, Row C-1:160, Row D-1:320, Row E-1:640, Row F-1:1280, Row G-1:2560, Row H-1:5120. Due to the paucity of information on the prevalence of endemic brucellosis in people in South Africa [51], the test was used as recommended and no adaptation made to interpret titres.

Subjects with insufficient blood for the $\operatorname{RBT}^{\circledR}(n=2)$ were excluded from the analysis. All samples were tested with the RBT ${ }^{\circledR}$, IgG ELISA $^{\circledR}$ and BrucellaCapt ${ }^{\circledR}$ tests. Samples that were seropositive on the ELISA IgG ${ }^{\circledR}$ were tested further using the IgM ELISA ${ }^{\circledR}$. Samples seronegative on the IgG ELISA ${ }^{\circledR}$, but seropositive using the RBT $^{\circledR}$, were also subjected to an IgM ELISA ${ }^{\circledR}$ test. This selective testing of samples using the IgM ELISA ${ }^{\circledR}$ was due a limited budget. The purpose was to detect the presence or absence of Brucella IgM antibodies in these selected samples to better understand the evolutionary stage of infection in the farm workers and veterinary officials. Stages of infection were considered along a continuum from a short evolution of infection (IgM seropositive, IgG seronegative) to a long evolution of infection (IgM seronegative, IgG seropositive, possible presence of blocking or non-agglutinating antibodies). As such, each seropositive person fell into one of five mutually exclusive groups depending on the outcome of a combination of tests: (i) $\mathrm{RBT}^{\circledR}$, IgM ELISA ${ }^{\circledR}$ positive and IgG ELISA ${ }^{\circledR}$ negative, (ii) $\mathrm{RBT}^{\circledR}$ negative and $\operatorname{IgM}, \operatorname{IgG}$ ELISA $^{\circledR}$ positive, (iii) RBT $^{\circledR}$, IgM ELISA ${ }^{\circledR}$ positive and IgG ELISA ${ }^{\circledR}$ positive, (iv) RBT $^{\circledR}$, IgG ELISA ${ }^{\circledR}$ positive and IgM ELISA ${ }^{\circledR}$ negative, and (v) RBT $^{\circledR}$, IgM ELISA $^{\circledR}$ negative and IgG ELISA ${ }^{\circledR}$ positive. Seropositive reactors on the BrucellaCapt ${ }^{\circledR}$ test were allocated to the group defined by the outcomes of the RBT ${ }^{\circledR}$, IgM ELISA ${ }^{\circledR}$ and IgG ELISA ${ }^{\circledR}$.

Subjects with test results for the IgG ELISA ${ }^{\circledR}$ that were classified as equivocal $(n=3)$ were removed from the analysis. Titres were determined using the BrucellaCapt ${ }^{\circledR}$ test. A titre of greater or equal to 1:320, was considered positive.

The RBT ${ }^{\circledR}$ and IgM ELISA ${ }^{\circledR}$ were used in series to increase the specificity of RBT $^{\circledR}$ to detect Brucella IgM, as an indication of infection of a short evolution. To detect Brucella $\mathrm{IgG}$, an indication of a possibly longer evolution, we used the IgG ELISA ${ }^{\circledR}$ test. The BrucellaCapt ${ }^{\circledR}$ test was used, with the recommended cut-off titre of 1:320, for the detection of possible clinical brucellosis with either a short or long evolution. All tests were performed according to the manufacturer's guidelines.

\subsection{Data Management and Analysis}

Completed questionnaires were captured into the electronic form function of Microsoft ${ }^{\circledR}$ Access $^{\circledR}$ (2013), for Microsoft 365, Redmond, WA, USA. Laboratory results were captured into the appropriate record, by matching the unique identifiers of the samples.

Descriptive statistics were done in Microsoft ${ }^{\circledR}$ Excel $^{\circledR}$ for Microsoft 365, Redmond, WA, USA. Univariable analyses were conducted in STATA $14^{\circledR}$ StataCorp College Station Texas 77845 United States, for outcomes (1) RBT ${ }^{\circledR}$, IgM ELISA ${ }^{\circledR}$ positive and IgG ELISA ${ }^{\circledR}$ 
positive, (2) RBT $^{\circledR}$. IgG ELISA ${ }^{\circledR}$ positive and IgM ELISA ${ }^{\circledR}$ negative, and (3) $\operatorname{RBT}^{\circledR}, \operatorname{IgM}$ ELISA $^{\circledR}$ negative and IgG ELISA ${ }^{\circledR}$ positive and (4) BrucellaCapt ${ }^{\circledR}$ seropositivity amongst farm workers and veterinary officials $(N=230)$.

Univariable associations between each variable and the outcomes were assessed using Fisher's exact test. Variables with $p<0.20$ were selected for inclusion into mixed effects multivariable logistic regression models. Farm was included as a random effect in all three models. Veterinary officials were clustered into three groups, according to the State Vet Area they serviced. Each cluster was allocated a unique number and added to the farm variable. Three separate mixed effects logistic regression models were fit to identify risk factors for increasing evolution of infection: (1) RBT $^{\circledR}, \operatorname{IgM}$ ELISA $^{\circledR}$ positive and IgG ELISA ${ }^{\circledR}$ positive (short evolution), (2) RBT $^{\circledR}$, IgG ELISA $^{\circledR}$ positive and IgM ELISA ${ }^{\circledR}$ negative (long evolution), and most likely inactive or resolved infection but indicative of exposure to Brucella spp (3) RBT $^{\circledR}$, IgM ELISA ${ }^{\circledR}$ negative and IgG ELISA ${ }^{\circledR}$ (exposure/inactive or resolved infection). Variables with $p>0.05$ in the models, were systematically removed by backward elimination $[57,58]$.

\section{Conclusions}

Evidence of cattle handler exposure to Brucella on cattle farms participating in the bovine brucellosis control programme in Gauteng varies depending on the serological screening test used. However, when tests results were combined to illuminate the evolution of infection in this group, significant risk factors and symptoms were found to be associated with infection of short and long evolution. This, in addition to the finding of poor health seeking behaviour in response to brucellosis-like symptoms among farm workers and veterinary officials with these antibody profiles, strongly suggest the presence of undetected cases of human brucellosis on cattle farms.

Since this study was undertaken as a pilot study, our first recommendation is to establish a representative sampling frame of occupationally exposed persons to attain a sample large and representative enough to determine the true endemic seroprevalence of brucellosis in this group and to obtain a better measure of odds ratios and confidence intervals for risk factors [16]. To achieve this, we recommend that people exposed to cattle herds in Gauteng be routinely screened for brucellosis using the $\mathrm{RBT}^{\circledR}$ test as described in Diaz et al. (2011) to facilitate an early detection and response to brucellosis in these occupationally exposed persons and their families [22]. In brief, RBT ${ }^{\circledR}$ should be used on plain serum and, if positive, $\mathrm{RBT}^{\circledR}$ on serum dilutions up to $1 / 32$. Dilutions should be contrasted with clinical symptoms (if any). It is also recommended that medical practitioners in SA be made aware of the clinical symptoms of both short and long evolution brucellosis and the risk of brucellosis amongst persons occupationally exposed to cattle herds in Gauteng province. With greater awareness, medical practitioners can monitor the endemic seroprevalence of brucellosis to adapt cut-off points for commercially available serological tests, such as the BrucellaCapt ${ }^{\circledR}$. Awareness programmes to increase knowledge of human and cattle symptoms of brucellosis are recommended to be part of the routine veterinary regulatory service to these farms. Occupational health and safety measures to protect the health of veterinary officials should be implemented and monitored.

Author Contributions: Conceptualization, D.A.A., K.G. and J.R.; methodology, J.R., D.A.A.; software, P.N.T., E.M.C.E.; validation, K.G.; formal analysis, K.G., P.N.T. and E.M.C.E..; investigation, K.G., B.N.H.; resources, B.N.H. and J.R.; data curation, K.G.; writing-original draft preparation, K.G.; writing-review and editing, P.N.T., B.N.H. and E.M.C.E.; visualization, K.G.; supervision, P.N.T., E.M.C.E. and D.A.A.; project administration, P.N.T.; funding acquisition, D.A.A. All authors have read and agreed to the published version of the manuscript.

Funding: This research was jointly funded by the University of Pretoria Animal and Zoonotic Diseases Institutional Research Theme (AZD IRT) and by the South African Health and Welfare Sector Education and Training Authority (HWSETA) project number F-ABER-GOV. 
Institutional Review Board Statement: The study was conducted according to the guidelines of the University of Pretoria, and approved by the Research Ethics Committee, Faculty of Health Sciences, University of Pretoria (74/2015) and the Animal Ethics committee of the University of Pretoria (V011-16).

Informed Consent Statement: Informed consent was obtained from all subjects involved in the study.

Data Availability Statement: Data are available on request from the Gauteng Department of Agriculture and Rural Development.

Acknowledgments: This study would not have been possible without the support and encouragement of the Gauteng Department of Agriculture and Rural Development. The authors wish to acknowledge the animal health technicians (AHTs), state vets and managers of the department. This study would not have been possible without the following people: Nolo Moeketsi (data capturer), Gerbrand van der Zel and Theo Serebolo (epidemiology AHTs), Peter Geertsma and Johan Walters. We also wish to acknowledge Anastasia Trataris-Rebisz for performing the testing of the human samples.

Conflicts of Interest: The authors declare no conflict of interest. The funders had no role in the design of the study; in the collection, analyses, or interpretation of data; in the writing of the manuscript, or in the decision to publish the results.

\section{References}

1. WHO. Research Priorities for Zoonoses and Marginalized Infections; WHO: Geneva, Switzerland, 2012.

2. WHO. The Control of Neglected Zoonotic Diseases: From Advocacy to Action; WHO: Geneva, Switzerland, 2014.

3. WHO. The Control of Neglected Zoonotic Diseases: A Route to Poverty Alleviation; WHO: Geneva, Switzerland, 2005.

4. Ducrotoy, M.; Bertu, W.J.; Matope, G.; Cadmus, S.; Conde-Álvarez, R.; Gusi, A.M.; Welburn, S.; Ocholi, R.; Blasco, J.M.; Moriyón, I. Brucellosis in Sub-Saharan Africa: Current challenges for management, diagnosis and control. Acta Trop. 2017, 165, 179-193. [CrossRef]

5. Dean, A.S.; Crump, L.; Greter, H.; Hattendorf, J.; Schelling, E.; Zinsstag, J. Clinical Manifestations of Human Brucellosis: A Systematic Review and Meta-Analysis. PLoS Negl. Trop. Dis. 2012, 6, e1929. [CrossRef] [PubMed]

6. Doganay, M.; Aygen, B. Human brucellosis: An overview. Int. J. Infect. Dis. 2003, 7, 173-182. [CrossRef]

7. Corbel, M.J.; Alton, G.G.; Banai, M.; Dias, R.A.; Dranovskaia, B.A.; Elberg, S.S.; Garin-Bastuji, B.; Kolar, J.; Macmillan, A.; Mantovani, A.; et al. Brucellosis in Humans and Animals; Weltgesundheitsorganisation, FAO, Eds.; WHO/FAO: Geneva, Switzerland, 2006; p. 89.

8. Wyatt, H. Lessons from the history of brucellosis. Rev. Sci. Tech. 2013, 32, 17-25. [CrossRef]

9. Nicoletti, P. Brucellosis: Past, present and future. Prilozi 2010, 31, 21-32. [PubMed]

10. Godfroid, J.; Al-Dahouk, S.; Pappas, G.; Roth, F.; Matope, G.; Muma, J.; Marcotty, T.; Pfeiffer, D.; Skjerve, E. A “One Health” surveillance and control of brucellosis in developing countries: Moving away from improvisation. Comp. Immunol. Microbiol. Infect. Dis. 2013, 36, 241-248. [CrossRef]

11. McDermott, J.; Grace, D.; Zinsstag, J. Economics of brucellosis impact and control in low-income countries. Rev. Sci. Tech. 2013, 32, 249-261. [CrossRef]

12. Mufinda, F.; Boinas, F.; Nunes, C. A survey on knowledge and practices of brucellosis among occupationally exposed livestock workers in Namibe province, Angola. Afr. J. Sci. Res. 2015, 4, 29-38.

13. Kansiime, C.; Mugisha, A.; Makumbi, F.; Mugisha, S.; Rwego, I.B.; Sempa, J.; Kiwanuka, S.N.; Asiimwe, B.B.; Rutebemberwa, E. Knowledge and perceptions of brucellosis in the pastoral communities adjacent to Lake Mburo National Park, Uganda. BMC Public Health 2014, 14, 242. [CrossRef]

14. Zinsstag, J.; Roth, F.; Orkhon, D.; Chimed-Ochir, G.; Nansalmaa, M.; Kolar, J.; Vounatsou, P. A model of animal-human brucellosis transmission in Mongolia. Prev. Vet. Med. 2005, 69, 77-95. [CrossRef]

15. Benon, A.B.; Juliet, K.; Samuel, M.; Catherine, K.; Benjamin, S.; Michael, M.; Innocent, R.B. Health workers' knowledge of zoonotic diseases in an endemic region of Western Uganda. Zoonoses Public Health 2018, 65, 850-858. [CrossRef]

16. Rahman, A.A.; Dirk, B.; Fretin, D.; Saegerman, C.; Ahmed, M.U.; Muhammad, N.; Hossain, A.; Abatih, E. Seroprevalence and risk factors for brucellosis in a high-risk group of individuals in Bangladesh. Foodborne Pathog. Dis. 2012, 9, 190-197. [CrossRef] [PubMed]

17. Celi Erazo, M.L.; Ron Román, J.; Ron Garrido, L.; Abatih, E.; Vizcaíno Ordóñez, L.; Calva Pacheco, J.; González Andrade, P.; Berkvens, D.; Benítez Ortiz, W.V.; Brandt, J. Human brucellosis in northwest Ecuador: Typifying Brucella spp., seroprevalence, and associated risk factors. Vector-Borne Zoonotic Dis. 2014, 14, 124-133. [CrossRef]

18. Ali, S.; Ali, Q.; Neubauer, H.; Melzer, F.; Elschner, M.; Khan, I.; Abatih, E.N.; Ullah, N.; Irfan, M.; Akhter, S. Seroprevalence and risk factors associated with brucellosis as a professional hazard in Pakistan. Foodborne Pathog. Dis. 2013, 10, 500-505. [CrossRef]

19. Al Dahouk, S.; Nöckler, K. Implications of laboratory diagnosis on brucellosis therapy. Expert Rev. Anti-Infect. Ther. 2011, 9, 833-845. [CrossRef] [PubMed] 
20. Al Dahouk, S.; Sprague, L.; Neubauer, H. New developments in the diagnostic procedures for zoonotic brucellosis in humans. Rev. Sci. Tech. 2013, 32, 177-188. [CrossRef] [PubMed]

21. Al-Dahouk, S.; Tomaso, H.; Nöckler, K.; Neubauer, H.; Frangoulidis, D. Laboratory-based diagnosis of brucellosis-A review of the literature. Part II: Serological tests for brucellosis. Clin. Lab. 2003, 49, 577-589.

22. Díaz, R.; Casanova, A.; Ariza, J.; Moriyón, I. The Rose Bengal Test in Human Brucellosis: A Neglected Test for the Diagnosis of a Neglected Disease. PLoS Negl. Trop. Dis. 2011, 5, e950. [CrossRef]

23. Vircell. Rose Bengal Test for in vitro diagnostic use. In Vircell, S.L. Pza. Dominguez Ortiz l. Poligono Industrial Dos de Octubre. 18320 Santa Fe; Vircell: Granada, Spain, 2005.

24. Hasibi, M.; Jafari, S.; Mortazavi, H.; Asadollahi, M.; Djavid, G.E. Determination of the accuracy and optimal cut-off point for ELISA test in diagnosis of human brucellosis in Iran. Acta Med Iran 2013, 687-692.

25. Peeridogaheh, H.; Golmohammadi, M.G.; Pourfarzi, F. Evaluation of ELISA and BrucellaCapt ${ }^{\circledR}$ tests for diagnosis of human Brucellosis. Iran. J. Microbiol. 2013, 5, 14.

26. OrduñA, A.; Almaraz, A.; Prado, A.; Gutierrez, M.P.N.; Garcia-Pascual, A.; DueñAs, A.; Cuervo, M.; Abad, R.; HernáNdez, B.; Lorenzo, B.; et al. Evaluation of an Immunocapture-Agglutination Test (BrucellaCapt ${ }^{\circledR}$ ) for Serodiagnosis of Human Brucellosis. J. Clin. Microbiol. 2000, 38, 4000-4005. [CrossRef] [PubMed]

27. Franco, M.P.; Mulder, M.; Gilman, R.H.; Smits, H.L. Human brucellosis. Lancet Infect. Dis. 2007, 7, 775-786. [CrossRef]

28. Dean, A.S.; Crump, L.; Greter, H.; Schelling, E.; Zinsstag, J. Global Burden of Human Brucellosis: A Systematic Review of Disease Frequency. PLoS Negl. Trop. Dis. 2012, 6, e1865. [CrossRef] [PubMed]

29. Animut, A.; Mekonnen, Y.; Shimelis, D.; Ephraim, E. Febrile illnesses of different etiology among outpatients in four health centers in Northwestern Ethiopia. Jpn J. Infect. Dis. 2009, 62, 107-110. [PubMed]

30. Bouley, A.J.; Biggs, H.M.; Stoddard, R.A.; Morrissey, A.B.; Bartlett, J.A.; Afwamba, I.A.; Maro, V.P.; Kinabo, G.D.; Saganda, W.; Cleaveland, S.; et al. Brucellosis among Hospitalized Febrile Patients in Northern Tanzania. Am. J. Trop. Med. Hyg. 2012, 87, 1105-1111. [CrossRef] [PubMed]

31. Dean, A.S.; Bonfoh, B.; Kulo, A.E.; Boukaya, G.A.; Amidou, M.; Hattendorf, J.; Pilo, P.; Schelling, E. Epidemiology of Brucellosis and Q Fever in Linked Human and Animal Populations in Northern Togo. PLoS ONE 2013, 8, e71501. [CrossRef]

32. Swai, E.S.; Schoonman, L. Human brucellosis: Seroprevalence and risk factors related to high risk occupational groups in Tanga Municipality, Tanzania. Zoonoses Public Health 2009, 56, 183-187. [CrossRef] [PubMed]

33. Schelling, E.; Diguimbaye, C.; Daoud, S.; Nicolet, J.; Boerlin, P.; Tanner, M.; Zinsstag, J. Brucellosis and Q-fever seroprevalences of nomadic pastoralists and their livestock in Chad. Prev. Vet. Med. 2003, 61, 279-293. [CrossRef]

34. Kassahun, J.; Yimer, E.; Geyid, A.; Abebe, P.; Newayeselassie, B.; Zewdie, B.; Beyene, M.; Bekele, A. Sero-prevalence of brucellosis in occupationally exposed people in Addis Ababa, Ethiopia. Ethiop. Med. J. 2006, 44, 245-252.

35. Frean, J.; Cloete, A.; Rossouw, J.; Blumberg, L. Brucellosis in South Africa-A Notifiable Medical Condition. NICD Commun. Dis. Commun. 2018, 16, 110-117.

36. Wojno, J.M.; Moodley, C.; Pienaar, J.; Beylis, N.; Jacobsz, L.; Nicol, M.P.; Rossouw, J.; Bamford, C. Human brucellosis in South Africa: Public health and diagnostic pitfalls. SAMJ S. Afr. Med. J. 2016, 106, 883-885. [CrossRef]

37. Govindasamy, K. Human brucellosis in South Africa: A review for medical practitioners. SAMJ S. Afr. Med. J. 2020, 110, 646-651. [CrossRef] [PubMed]

38. Zhang, N.; Zhou, H.; Huang, D.S.; Guan, P. Brucellosis awareness and knowledge in communities worldwide: A systematic review and meta-analysis of 79 observational studies. PLoS Negl. Trop. Dis. 2019, 13, e0007366. [CrossRef] [PubMed]

39. Cloete, A.; Gerstenberg, C.; Mayet, N.; Tempia, S. Brucellosis knowledge, attitudes and practices of a South African communal cattle keeper group. Onderstepoort J. Vet. Res. 2019, 86, 1-10. [CrossRef] [PubMed]

40. Babazadeh, T.; Nadrian, H.; Ranjbaran, S.; Rezakhani Moghaddam, H.; Aghemiri, M. Cognitive factors associated with brucellosis preventive behaviours among diagnosed patients: An application of Empowerment Model. East. Mediterr. Health J. 2019, 25, 567-574. [CrossRef]

41. Kunda, J.; Fitzpatrick, J.; Kazwala, R.; French, N.P.; Shirima, G.; Macmillan, A.; Kambarage, D.; Bronsvoort, M.; Cleaveland, S. Health-seeking behaviour of human brucellosis cases in rural Tanzania. BMC Public Health 2007, 7, 1-7. [CrossRef]

42. Kutlu, M.; Ergonul, O.; Sayin-Kutlu, S.; Guven, T.; Ustun, C.; Alp-Cavus, S.; Ozturk, S.B.; Acicbe, O.; Akalin, S.; Tekin, R. Risk factors for occupational brucellosis among veterinary personnel in Turkey. Prev. Vet. Med. 2014, 117, 52-58. [CrossRef]

43. Pereira, C.R.; Cotrim De Almeida, J.V.F.; Cardoso De Oliveira, I.R.; Faria De Oliveira, L.; Pereira, L.J.; Zangerônimo, M.G.; Lage, A.P.; Dorneles, E.M.S. Occupational exposure to Brucella spp.: A systematic review and meta-analysis. PLoS Negl. Trop. Dis. 2020, 14, e0008164. [CrossRef]

44. Lewis, J.S. Brucellosis in Krugersdorp, with a review of the problem in Southern Africa. S. Afr. Med. J. 1959, 33, $177-181$.

45. Schrire, L. Human brucellosis in South Africa. S. Afr. Med. J. 1962, 36, 342-349.

46. Robinson, R.; Metcalfe, R. Zoonotic infections in veterinarians. N. Z. Vet. J. 1976, 24, 201-210. [CrossRef] [PubMed]

47. Sacks, N.; van Rensburg, A.J. Clinical aspects of chronic brucellosis. S. Afr. Med. J. 1976, 50, 725-728. [PubMed]

48. Gummow, B. A survey of zoonotic diseases contracted by South African veterinarians. J. S. Afr. Vet. Assoc. 2003, 74, 72-76. [CrossRef]

49. OIE. Bovine brucellosis. In Manual of Diagnostic Tests and Vaccines for Terrestrial Animals; Office International des EpiZooties: Paris, France, 2008; p. 3. 
50. Govindasamy, K. Animal Health Technician Brucellosis Risk Survey; Gauteng Department of Agriculture and Rural Development: Pretoria, South Africa, 2016; Unpublished report.

51. Govindasamy, K. A One Health Systems Approach to the Epidemiology, Management and Regulatory Control of Bovine Brucellosis at the Human-Cattle-Farm Interface in Gauteng, South Africa; University of Pretoria: Pretoria, South Africa, 2020.

52. Vircell. Brucella ELISA IgG for in vitro diagnostic use. In Vircell, S.L. Parque Tecnologico de la Salud, Avicena 8, 18016 Granada, Spain; Vircell: Granada, Spain, 2006.

53. Foz, A.; Pellicer, T.; Comerma, J.; Ariza, J. Specificity of ELISA anti-immunoglobulin G conjugate in the diagnosis of human brucellosis. Eur. J. Clin. Microbiol. 1985, 4, 138-139. [CrossRef] [PubMed]

54. Vircell. Vircell FAQ BrucellaCapt ${ }^{\circledR}$. Available online: https://en.vircell.com/support/faqs/3-BrucellaCapt ${ }^{\circledR} /($ accessed on 24 October 2019).

55. Vircell. BrucellaCapt ${ }^{\circledR}$ for in vitro diagnostic use. In Vircell, S.L. Parque Tecnologico de la Salud, Avicena 8, 18016 Granada, Spain; Vircell: Granada, Spain, 2014.

56. Vircell. Brucella ELISA IgM for in vitro diagnostic use. In Vircell, S.L. Parque Tecnologico de la Salud, Avicena 8, 18016 Granada, Spain; Vircell: Granada, Spain, 2006.

57. Kleinbaum, D.G.; Klein, M. Logistic Regression: A Self Learning Text, 3rd ed.; Springer: New York, NY, USA; Dordrecht, The Netherlands; Heidelberg, Germany; London, UK, 2010. [CrossRef]

58. Tabachnick, B.G.; Fidell, L.S. Using Multivariate Statistics, 4th ed.; Allyn and Bacon: Boston, MA, USA, 2001. 